\title{
Towards a Globalisation of Law? Comments from the European Perspective in View of the Experiences with the Europeanisation of Law
}

\author{
Thomas Schmitz ${ }^{1}$ \\ \{tschmit1@gwdg.de\} \\ ${ }^{1}$ DAAD Lecturer in law at Universitas Gadjah Mada, Yogyakarta \\ Ausserplanmäßiger Professor (adjunct professor) at the Georg-August-Universität Göttingen, \\ Germany
}

\begin{abstract}
This article aims to contribute to the debate on globalization of law and the challenges of globalization. Today the COVID-19 pandemic has also had an impact on international trade. An understanding of globalization can be started with comments from a European perspective in view of the experience with a similar phenomenon, namely Europeanization of law. Europeanization of law is an example of geo-regionalization of law. Geo-regionalization and legal globalization are different forms of the same phenomenon, the internationalization of law. First, there will be no globalization of law without commitment to the rule of law. Second, there will be no globalization of law without multilateralism. Third, there will be no globalization of law without demanding requirements for the effective domestic implementation and enforcement of the global rules and standards. Fourth, there will be no globalization of law without sophisticated conceptional precautions to ensure compliance with the global rules and standards. Fifth, there will be no globalization of law without global courts of justice
\end{abstract}

Keywords: Globalisation of law, Europeanisation of law, in particular administrative law and constitutional law, European Union - legal nature; supranational union, integration through law, direct effect and primacy of European Union law, implementation of European Union law by the member states, European Court of Justice, rule of law, further developing of law, general principles of law, effectiveness of the law (effet utile).

\section{Introduction}

For several decades, the world has been undergoing a process of transformation. The old political world order, emanating from the $19^{\text {th }}$ century, where the independent individual nationstate was the basis of all power, law and politics, is dramatically changing. The world has seen the development from the solitary loner state to free trade, joint markets, economic interpenetration and interdependence, manifold and close international cooperation and booming international mobility. This development has been accompanied by a rise of global law and institutions. This raises the question: Are we on the way towards a globalisation of law? The following article will contribute to the debate with comments from the European perspective in view of the experiences with a similar phenomenon, the Europeanisation of law.

\subsection{What is globalisation of law?}

For two decades there has been a heterogeneous, sometimes blurred discussion about the globalisation of law, often rather from a political science or social science than a legal science perspective. [1] However, is this discussion backed by hard facts, in line with the fundamentals of law on this planet or is it for the time being still wishful thinking? The first step towards a realistic discussion is a realistic definition of "globalisation of law". The law of the modern state has never been totally free from external influences. Not every slightest influence of global norms on the domestic law in the wake of the growing international trade, mobility and cooperation "globalises" the domestic law. Globalisation of law is more: It is the profound transformation or even replacement of national (domestic) law by legal standards and other legal norms of global international law. It is a form of internationalisation of law.[2] 


\subsection{Background: The Unaffected Sovereignty of the State - Even in Times of Geo- Regionalisation and Globalisation}

For a correct assessment of the dimension and limits of the phenomenon it is necessary to keep in mind an important background: the unchallenged legal world order of sovereign territorial states. [3] Even under the conditions of advanced globalisation in the $21^{\text {st }}$ century, our planet does not constitute a legal unity but is divided into independent (sovereign) territorial states formed by distinct peoples, each state exercising an exclusive power to rule (state power) on its state territory. This Westphalian order is nowhere contested on this planet, neither by any state, nor by any people, nor by any political ideology. It focuses on the sovereignty of the state: the underived and independent legal capacity to act in internal and external affairs, which is only subject to a few basic restrictions under Ius cogens in public international law but otherwise unlimited. Sovereignty is something absolute and therefore cannot be affected by the recent developments (which may, however, one day put the whole concept into question). The sovereignty of the state includes its control over all public power exercised in the state and, thus, over all law which is valid in the state. Consequently, there can be no globalisation of law without the consent of the state. The state may accept global norms only for economic and political reasons but is always legally free to reject them and bear the consequences. Thus, the responsibility for any globalisation of law ultimately lies with the individual state.

\subsection{The First Few Signs for A Globalisation of Law}

So far only a few signs for a globalisation of law can be identified. There is still a very limited replacement of national law by global international law. Global international treaties and binding decisions of international organisations usually need to be implemented into the domestic law or complement it but do not replace it. The United Nations Convention on Contracts for the International Sale of Goods (CISG) of 1980 is an exception: It offers international trading partners an autonomous global sales law for contracts of international sales of goods, which optionally replaces the sales law of the states of the contracting parties. While such examples are still rare, there is already a growing influence of global standards and regulations on the national law. This is about legally binding rules and standards that need to be implemented into or achieved by the national law. Examples can be found in the WTO-Agreements, the UN environmental and climate protection agreements and the global human rights treaties. The WTO Agreements provide for an effective enforcement mechanism but also the global human rights treaties ensure by the instruments of recommendations and general comments of their treaty bodies that the global standards do not remain a vague idea but are concretised and developed in practice. However, this development is still at an early stage. Often it rather concerns details than basic concepts of the law, and its impact on the national law is still moderate.

\section{4. Prospects: from Economic Globalisation to Globalisation of Law or On The Way To Deglobalisation?}

Will this development lead to a comprehensive globalisation of law? The fact that many developing and newly industrialised countries continue to emphasise the importance of the sovereignty of the individual state, raises doubts. Moreover, nationalist populism, in particular in the Western countries, poses a growing threat to globalisation: "Make my country great again"? This slogan of the American president Donald Trump does not only stand for economic protectionism and the attempt to renationalise the production of goods but also for a countermovement against any globalisation of law. Populist regimes want to get free from any legal commitments that may restrict their arbitrary rule. So, it is not a surprise that the present American government is sabotaging the UN, the WTO, the WHO and other global institutions and has withdrawn from the Paris Climate Agreement and other multilateral international treaties. Furthermore, the coronavirus crisis, which has seriously affected the global trade and revealed in many contexts the interdependence and vulnerability of the individual states, may have a lasting impact. Globalisation is viewed more sceptically and critically now, and since it had already slowed down before, the discussion about deglobalisation, which had already started, has intensified. [4] Deglobalisation would present a serious threat for the emerging economies in Southeast Asia. However, the reasons for the globalisation have not vanished and the more critical perspective on it will probably not lead to a regression but to more regulation with regard to the reliability of supply and to social, environmental and human rights standards. Thus, the coronavirus crisis may rather expedite than hinder the globalisation of law. 


\section{Result and Discussion}

\subsection{A Historical Precedent: The Europeanisation of Law}

The globalisation of law is not unique. There has been a historical precedent: the Europeanisation of law. A look at this phenomenon, which was a concern to European lawyers in the 1990s, will be helpful to understand what to expect.

\subsubsection{Geo-regionalisation and globalisation as different forms of internationalisation of law}

In Europe, the national law is not only under the influence of global international law but, first of all, of European law. The Europeanisation of law is an example for a geo-regionalisation of law; more examples in other parts of the world may follow. Geo-regionalisation and globalisation of law are different forms of the same kind of phenomena, the internationalisation of law.

\subsubsection{The integration of Europe in a supranational union}

The Europeanisation of law must be seen against the background of the integration of Europe in a new form of organisation, the supranational union. The European Union is not an international institution like others. It is a non-state but state-like supranational organisation of integration which performs on a large scale public missions by the exercise of supranational public power in its member states, in particular through legislation and regulation. It is the first representative of a new form of organisation, which emerged in the process of European integration and is designed for a long transition from the (relatively small) nation-state to the (much larger) civilisation state. [5] This organisation even has its own legal order - not like an ordinary international organisation but like a state. The unconventional design of the European Union has sparked a long, intensive scholarly debate about its legal nature. The German Federal Constitutional Court developed a state-centred "Staatenverbund" doctrine (the Union as a "compound of states"). [6] Some scholars consider the Union's Founding Treaties a constitution and talk about a "Verfassungsverbund" ["constitutional compound"] [7] or a "Staaten- und Verfassungsverbund" ["compound of states and constitutions"]. [8] However, since the new form of organisation can only be understood in depth by focusing not on the member states but on the Union and its function in the process of supranational integration, it is instead appropriate to classify the European Union as a supranational union.[9]

\subsubsection{The European basic concept of integration through law [10]}

The integration of Europe in this new form of organisation is based on the innovative concept of integration through law. This concept is the answer to the problem that the Union is not a state and does not have the physical means of a state but is similar to a state, fulfils many functions of a state and must meet expectations that are similar to those towards a state.

a) The whole integration is based on law and the respect for law. With few exceptions, the Union does not execute its law itself. It is generally confined to pass legal acts that the member states must implement, execute and enforce. Since most provisions concern the economy or have an economic effect, compliance is essential: Even small irregularities may cause serious distortions of competition in the internal market that would disadvantage those who follow the law and, thus, quickly jeopardise the whole integration process.

b) This is underlined by the fact that the Union has no coercive powers to enforce its law. It relies on the correct implementation, execution, and enforcement by the member states. Unlike in a federal state, there is no way to ultimately force a renitent member state to comply.

c) Against this background, it is not a surprise that there is a strong emphasis of the rule of law. The rule of law is the most important foundation of the European Union and one of the common fundamental values of the Union and its member states, as they are anchored in art. 2 of the Treaty on the European Union (= EU Treaty). For accession candidates, the demanding requirements of the rule of law represent a serious obstacle for entering the Union.

d) Finally, a powerful own court of justice has the mission to "ensure that ... the law is observed" (original wording of art. 19 EU Treaty). The European Court of Justice (= ECJ) in Luxembourg [11] virtually functions as both, a constitutional court and a supreme court. It 
cooperates with the courts of the member states, which may ask it under art. 267 of the Treaty on the Functioning of the European Union (= FEU Treaty) for preliminary rulings on the validity and interpretation of Union law. So, in the European Union, unlike in ASEAN, legal disputes are settled by a court and not by negotiations between governments. This is a logical consequence of the rule of law which refers to the law and not to politics. Legal problems must be solved by lawyers, not by politicians. This will also be an essential precondition for the globalisation of law.

\subsubsection{The Characteristic Features of European Union law}

What are the characteristic features of European Union law that set it apart from the law of other organisations based on public international law and played a role in the Europeanisation of law?

a) The autonomy of Union law: The Founding Treaties have created a distinct legal order of its own that is not an annex to national law and also apart from public international law. [12] In particular, the Union is not bound to any clauses in the constitutions of the member states. [13]

b) The direct effect of Union law in the member states: All public authorities and also the citizens are directly bound to the law of the European Union without intermediate national legislation or other national acts (with the exception of directives, which must first be transposed to the national law). This also applies to the Founding Treaties, which are directly applicable. [14] Thus, in the European Union, except for directives, the classical problem of international organisations, that their binding rules are not, not correctly or belatedly implemented into the national law, does not exist.

c) The unity of Union law is essential for the functioning of the Union. To avoid disparities endangering the integration process, the law is exactly the same in all member states, with uniform validity and application and without regard to the specific features of the national law. Thus, any national distortion by invoking specific "national values" is prevented. This will also be essential for a real globalisation of law.

d) The primacy of Union law over national law: In case of conflict, the authorities and courts in the member states must not apply their national law but follow the European law. [15] Conflicts may be avoided by interpreting national law in conformity with Union law. [16] European law enjoys primacy even over national constitutional law. [17] as long as the constitutional identity of the member state (the fundamental values and ideas constituting the core of its constitution) is not affected. [18] It is a primacy in application, not in validity (the national law does not become void) but this does not make any practical difference.

\subsubsection{Factors Stimulating the Europeanisation of Law}

Which are the factors that have stimulated the Europeanisation of law?

a) In the Founding Treaties and later in the reform treaties the member states undertook farreaching, abstractly formulated commitments, the full scope of which only became clear over time. Since there had not been any process of supranational integration before, they could not know all the legal consequences this would involve. Notably the commitments in the internal market and the duty to respect, implement, execute and enforce the European law turned out to be more demanding and complex than anticipated.

b) The European Court of Justice has taken a prominent role as defender of Community respectively Union law [19] and motor of European integration. Since many essential rules for the functioning of the organisation were not expressly regulated in the Treaties, they needed to be worked out by jurisprudence. So the European Court of Justice proceeded to extensive judicial further development of law, often by the "discovery" of unwritten general principles of law. [20] Numerous references of national courts for preliminary rulings enabled it to adjudicate in detail on many fundamental questions, in particular on the obligations of the member states under the Treaties and on the Union's requirements for national law. This jurisprudence was broadly accepted by the member states who rarely used the option to overrule it by amending the Treaties. New member states needed to accept it in the accession treaty as a part of the "acquis communautaire". 
c) The obligation to interpret national law in conformity with Union law (see supra, II.4.d) has a Europeanising effect because often not the wording but a certain interpretation of a national provision causes the conflict with Union law. This problem occurs in particular with indefinite legal concepts. Often the Europeanisation of law has rather manifested in changes of jurisprudence or even administrative practice than in new national legislation.

d) The jurisprudence of the European Court of Justice strongly focuses on the effectiveness ("effet utile") of Union law. The practical effectiveness of the European legal norms has become the dominant criterion for their interpretation and application. Basically, this approach is just a consistent pursuit of the rule of law - the Court takes its mission to "ensure that ... the law is observed" (art. 19 EU Treaty) seriously. However, this has led to demanding requirements for and less discretion of the member states in the implementation, execution and enforcement of the European law. [21]

e) Finally, the growing sectoral legislation of the Union in more and more fields of law has led to a growing impact of the European on the national law. Nowadays there almost no fields of law anymore which have not been influenced by rules and standards of Union law. However, this is not a surprise but was intended and expected in the advancing integration process where every Treaty reform brought new legislative competences for the Union.

\subsubsection{Fields and Examples of the Europeanisation of Law}

a) Europeanisation of Administrative Law [22]

The Europeanisation of administrative law is not the most radical but the most striking example of Europeanisation of law:

aa) The story

The law of the European Union is generally executed by the member states based on their national administrative law. Administrative law is closely connected to the national political and legal system, its basic structures, concepts and traditions, and, thus, reflects more than other fields of law the legal-cultural heritage of the country. In the history of administrative law in Europe, three lines of traditions have emerged: the French, the German and the Common Law tradition; besides, some countries (e.g. the Netherlands, Sweden) developed unique regimes. In the wake of European integration, this traditional national administrative law has been heavily transformed by demanding European standards which often forced member states to alter or give up traditional concepts of their law. The European standards were developed by the European Court of Justice in the way of judicial further development of law (cf. supra, II.5.b), just concretising consistently and with a comparative approach the requirements of a strict commitment to the rule of law, with a special focus on the uniform and effective implementation of Union law in all member states.

In this process, the Court worked out many general principles of Community resp. Union law that reflect classical elements of the rule of law and were in general shared by all or most of the member states, such as the principle of legal certainty [23] and the protection of legitimate expectations [24], including the respect for acquired rights [25], the right to effective legal protection[26], the principle of proportionality [27] and principles of a fair administrative procedure [28] or "good [proper] administration" [29]. These principles must often be balanced with each other or with the need for uniform and effective implementation of the law. This balancing can be different in every legal order. Sometimes, a different balancing in the jurisprudence of the European Court of Justice forced individual member states to adapt their national solutions to those of the Union, at least in those areas where Union law was involved.

In the nineties, this development triggered the resistance of some prominent scholars. [30] In the discussion, some would consider the specific concepts and traditions of the national administrative law as elements of national identity. However, most experts of administrative law did not share this view and so the Europeanisation of administrative law was widely accepted.

bb) Examples for jurisprudence with a Europeanising effect

Only a small selection of the jurisprudence causing the Europeanisation of administrative law can be presented in this article. It may give non-European observers the impression that the European Court of Justice is acting like a governess of the member states, telling them all the time what to do and not to do. This impression is not entirely wrong: Most jurisprudence was triggered by dirty tricks of individual member states to avoid compliance with the European law in order to 
achieve an unjust advantage for their citizens and businesses. Such tricks often prompted the European Commission to file an action against the member state for failure to fulfil obligations (art. 258 FEU Treaty) or made a national court ask the ECJ for a preliminary ruling on the states' obligations in the implementation, execution or enforcement of the European Union law (art. 267 FEU Treaty).

(1) The foundations were already created in 1963 and 1964 with the leading cases van Gend \& Loos [31] and Costa/ENEL [32] In the first case, the European Court of Justice worked out that Community law was an independent legal order and that the Treaties were directly applicable in the member states. In the second, it stated the primacy of Community law over national law. In the case Internationale Handelsgesellschaft [33] it specified that there is even primacy over national constitutional law. Together with the obligation of the courts and authorities in the member states to interpret national law in light of (in conformity with) Community law [34] this set already the course towards Europeanisation of law.

(2) In the decision Deutsche Milchkontor [35] the Court reminded to the responsibility - but also obligation - of the member states to implement the Community law. It confirmed that this process was governed by the national administrative law but stressed that this must not affect the scope and effectiveness of Community law. For example, when recovering unduly paid Community aids (subsidies), the member states may apply national provisions excluding the recovery with regard to such considerations as protection of legitimate expectation, loss of unjustified enrichment, passing of time-limits etc. but the conditions must be the same as for the recovery of purely national benefits and the interests of the Community must be "taken fully into account".[36] In the case vin de table [37] the Court reminded the member states of their obligation to take, where necessary, coercive measures against their citizens to enforce the Community law. In case of unforeseeable problems, they are obliged to cooperate loyally with the European Commission to solve the problem.

(3) Several decisions of the European Court of Justice ensured the access of the citizen to legal protection in matters concerning the execution of the European law.[38] They forced Germany to slightly extend the right of action before the administrative courts. In the case Factortame [39] the Court decided that the national courts must grant interim relief if it is necessary to enforce Community law, regardless of any adverse provisions of national law. This forced the United Kingdom to introduce interim relief against statutory law irrespectively of the British doctrine of parliamentary sovereignty. Furthermore, since there had been cases of abuse, the Court defined restrictive conditions for interim relief against the implementation of Community law: It is only admissible in case of serious doubts as to the validity of a Community act and if the question is referred to the ECJ for preliminary ruling, the applicant is threatened with serious and irreparable damage and there is taken due account of the interest of the Community that its legal acts have full effect. [40] Thus, Germany needed to correct its sometimes too "generous" practice of granting interim relief in favour of the citizen.

(4) In the European internal market, state aids (public subsidies to domestic businesses) which may distort competition and affect trade between member states are prohibited (art. 107 FEU Treaty). State aids are monitored by the European Commission and new state aids must be notified to it (art. 108 FEU Treaty). In the case Alcan [41] the European Court of Justice worked out strict principles for the recovery of illegitimate states aids, which limit the sometimes, abusive recourse to rule of law principles in order to enable the domestic businesses to keep their illegitimate benefits: There will be no protection of legitimate expectations of the beneficiary if the state aid has not been notified to the European Commission. Furthermore, the national authorities must recover the aid without own discretion if the Commission orders it.

The European Court of Justice has affirmed the direct applicability of decisions of the European institutions addressed to the member states in favour of the citizen, if the decision is unconditional and sufficiently precise. [42]

In the spectacular decision Francovich of 1991 [43] the European Court of Justice introduced by judicial further development of law the legal institution of state liability for violation of Union law. The state liability even applies in case of violations of Union law by the national legislator (contrarily to the tradition of some member states, such as Germany) or supreme court. [44]. It is based on Union law but details may be regulated in line with the European standards in the national law.

Finally, the European Court of Justice has taken precautions to ensure the correct implementation of directives. Directives are general rules of Union law that do not apply directly but must be transposed into the law of the member states (cf. art. 288 sub-sect. 3 FEU Treaty). Member states often tend to transpose them sloppily or late. The Court stressed that they must implement them by law, not just by administrative practice or administrative provisions. [45] During the implementation period, they must refrain from taking any measure liable to compromise the 
directive's effect. [46] To avoid conflicts, any national law must be interpreted in conformity with the directive. [47] If a directive is not implemented in time, after the expiration of the implementation period it exceptionally applies directly in favour of the citizen if it is unconditional and sufficiently precise. [48] In this case, until the necessary national norms have been created, the domestic authorities or courts decide in their own competence about the appropriate implementation of the directive. Finally, in case of late or inadequate implementation, under the doctrine of state liability for violation of Union law the state must pay compensation to the citizen for damages. [49] Overall, this jurisprudence had a considerable impact on the administrative law of most member states.

\section{b) Europeanisation of Constitutional Law}

European integration also brought a Europeanisation of constitutional law. This Europeanisation was to some extent triggered by interpreting the national constitution in the light of European Union law; the German Federal Constitutional Court even postulated a "principle of the openness towards European law" ["Grundsatz der Europarechtsfreundlichkeit"]. [50] However, primarily it was caused by constitutional amendments. At the beginning, the constitutional implications of supranational integration were mostly ignored but in the nineties the Treaty of Maastricht raised the awareness of the need for a solid constitutional basis for the participation of the state in such a process. Many old and later many new member states inserted European integration clauses into their constitutions. [51] Actually, these clauses would need to cover at least the delegation of sovereign rights to the Union and the acceptance of the direct applicability and primacy of Union law. Other constitutional amendments were necessary to participate in new integration steps (e.g. to allow to join the monetary union, to recognize the role and independence of the European Central Bank or to extradite own citizens to other member states under the European arrest warrant) or to comply with newly agreed self-restraints (e.g. to establish constitutional limits for budgetary deficits). Finally, in some cases constitutional amendments were necessary to adapt the constitution to requirements under Union law whose consequences only became apparent in time. For example, Germany needed to abolish the constitutional prohibition to employ women in the armed military service (art. 12a (4) Basic Law), since this prohibition, which intended to protect women but prevented them from pursuing a career in the armed forces, turned out to violate the principle of equal treatment of men and women under Union law. [52]

Moreover, there is another side of Europeanisation of constitutional law, which is not directly linked to the European Union: the strong influence of the jurisprudence of the European Court of Human Rights in Strasbourg on the interpretation of fundamental rights and rule of law principles in the national constitutions. Theoretically, the rights and principles anchored in the European Convention of Human Rights are different from those in the national constitutions, but often in both cases the wording is vague and the substance highly depends on the interpretation by the relevant court. In these cases, the convincing reasoning of the European Court of Human Rights has often prompted the national constitutional courts to adopt a similar position in the interpretation of their national constitutional law (or even to give up their previous position).[53] In Spain, art. 10(2) of the Spanish Constitution of 1978 even provides for this. In particular, the East European constitutional courts have orientated themselves by the jurisprudence of the Strasbourg court when developing their own free and democratic fundamental rights doctrine. Furthermore, the constitutional courts often orientate themselves by the jurisprudence of their European colleagues, in particular the German Federal Constitutional Court. This has led to a panEuropean discussion of many upcoming questions, in particular in the fields of rule of law and fundamental rights.

\section{c) Europeanisation of Other Fields of Law}

In almost seven decades of European integration, European law has profoundly transformed or even replaced the domestic law in numerous fields of law. This was intended and expected in the integration process. Since the European Communities started with a customs union (see now art. 28 et seq. FEU Treaty), customs law was the first field of law, where European law would almost entirely replace the domestic law. Moreover, for more than twenty years, in the European monetary union (art. 119, 127 et seq. FEU Treaty), European law has totally replaced the national monetary law. Besides, the realisation and later the safeguard of a functioning European internal market required a comprehensive harmonisation of economic law, often by the approximation of national laws by European legal acts (under art. 114 et seq., 46, 50, 53 FEU Treaty). Furthermore, there has been a strong transformation or even predetermination of the domestic law in the fields of agricultural law, environmental law, [54] asylum and refugee law, [55] consumer protection 
law, [55] public procurement law and data protection law. The European Union's General Data Protection Regulation [57] is the most progressive and most-noticed legislation in its field worldwide. Finally, elements of Europeanisation can be found in several fields of civil law (e.g. contract law, international private law) [58] and even in criminal law, where a European arrest warrant has been introduced. [59]

\section{Conclusions}

\subsection{Lessons on the Globalisation of Law Drawn from the Experiences with the Europeanisation of Law}

What lessons on the globalisation of law can we draw from the experiences with the Europeanisation of law?

1) First, there will be no globalisation of law without commitment to the rule of law. The Europeanisation of law could only happen because European integration is based on law. If in the global trade and cooperation the law is not taken seriously in some countries and this is tolerated by their international partners, there will be not enough political pressure to allow global norms and standards to influence the domestic law. In particular, globalisation of law cannot happen in a world of populist and totalitarian regimes.

2) Second, there will be no globalisation of law without multilateralism. The European integration process, which led to the Europeanisation of law, was always based on the firm desire to overcome national egoism and to find general solutions that were fair to all parties, to big and small, wealthy and poor, highly and less developed member states. A globalisation of law will require universal standards in universal treaties, not a cacophony of heterogeneous bilateral agreements, which would often be imposed on the weaker partners by hegemonial powers. Consequently, for the coming years, a globalisation of law is hardly conceivable if the American president Donald Trump is re-elected.

3) Third, there will be no globalisation of law without demanding requirements for the effective domestic implementation and enforcement of the global rules and standards. These requirements must ensure that these rules and standards have a practical impact. Otherwise, the "globalisation of law" would only be symbolic.

4) Fourth, there will be no globalisation of law without sophisticated conceptional precautions to ensure compliance with the global rules and standards. They must prevent all dirty tricks and ensure compliance in every single case and under all circumstances, even if it is unpopular or detrimental to the interests of the national governments, authorities and businesses. Without such precautions, the effectiveness and, thus, the practical impact of the global law is not guaranteed. This may pose a challenge for Southeast Asian countries where it is not a matter of course that the law is enforced in the individual case. The precautions may include binding global requirements for an effective fight against corruption.

5) Fifth, there will be no globalisation of law without global courts of justice. The European example proves that systems based on international law that function well in the individual case are possible. However, they require independent, impartial, unpoliticised and highly respected international judicial bodies for the authoritative interpretation, intrinsic further development and effective enforcement of the international law in transparent, formalised legal proceedings. Private arbitration panels (as in international investment protection agreements), expert treaty bodies (as in global human rights treaties) or other soft solutions are not sufficient. The European example also shows that it is important that national courts have the option to ask global courts for preliminary rulings on difficult questions of the global law. The direct cooperation between national and global courts will be helpful to ensure the rule of law locally and globally, to create a mutual understanding between local and global lawyers and to achieve a smooth globalisation of law without severe ruptures. Finally, as a last resort, the global law needs to provide for special instruments (court orders, penalty payments, international sanctions etc.) for the enforcement of the judgements of the global courts.

So, we can draw the lesson from the experiences with the Europeanisation of law, as another form of internationalisation of law, that a real globalisation of law is possible if there is a global commitment to the rule of law and certain requirements, including the establishment of global courts of justice, are met. Will it happen in the near future? 


\section{References}

[1] See, as examples for the early and current discussion, Rüdiger Voigt (editor), Globalisierung des Rechts [Globalisation of Law], 2000; Wolf Heydebrand, From Globalisation of Law to Law under Globalisation, in: David Nelken; Johannes Feest (editors), Adapting Legal Cultures, 2001, p. 117 ff.; Tania Lieckweg, Das Recht der Weltgesellschaft [The Law of the Global Society], 2003, p. 1 ff.; Halliday, Terence C; Osinsky, Pavel: Globalization of Law, Annual Review of Sociology 2006, p. 447 ff., www.researchgate.net/publication/228352345_Globalization_of_Law; Jürgen Schwarze (editor), Globalisierung und Entstaatlichung des Rechts [Globalisation and Denationalisation of Law], 2008; Alison Brysk (editor), The Politics of the Globalization of Law, 2013; Auby, Jean-Bernard: Globalisation, Law and the State, 2017.

[2] See for another definition Terence Halliday; Pavel Osinsky (note 1), p. 447: "worldwide progression of transnational legal structures and discourses along the dimensions of extensity, intensity, velocity, and impact". This definition, however, is too wide and too vague for a clear delimitation of the phenomenon and therefore inappropriate for legal science.

[3] See, as examples for the early and current discussion, Rüdiger Voigt (editor), Globalisierung des Rechts [Globalisation of Law], 2000; Wolf Heydebrand, From Globalisation of Law to Law under Globalisation, in: David Nelken; Johannes Feest (editors), Adapting Legal Cultures, 2001, p. 117 ff.; Tania Lieckweg, Das Recht der Weltgesellschaft [The Law of the Global Society], 2003, p. 1 ff.; Halliday, Terence C; Osinsky, Pavel: Globalization of Law, Annual Review of Sociology 2006, p. 447 ff., www.researchgate.net/publication/228352345_Globalization_of_Law; Jürgen Schwarze (editor), Globalisierung und Entstaatlichung des Rechts [Globalisation and Denationalisation of Law], 2008; Alison Brysk (editor), The Politics of the Globalization of Law, 2013; Auby, Jean-Bernard: Globalisation, Law and the State, 2017.

[4] See, for example, the discussion of Peter Watkins, Linda Yueh and Michael Cox, in: London School of Economics and Political Science (editor), COVID-29 and Deglobalisation, LSE public event 30.04.2020, video accessible at www.youtube.com/watch?v=N93HHJ7xQSg; Andrés Ortega, The deglobalisation virus, Blog of the Elcano Royal Institute 17.03.2020, https://blog.realinstitutoelcano.org/en/thedeglobalisation-virus; Frederik van Til, Three Scenarios for Globalisation in a Post-COVID19 World, Clingendael Spectator 01.04.2020, https://spectator.clingendael.org/en/publication/three-scenarios-globalisation-post-covid-19world; Douglas Irwin, The pandemic adds momentum to the deglobalisation trend, column at VOX, CEPR Policy Portal 05.05.2020, https://voxeu.org/article/pandemic-adds-momentumdeglobalisation-trend; Finbarr Livesey, Unpacking the possibilities of deglobalisation, Cambridge Journal of Regions, Economy and Society 11 (2018), p. 177 ff., https://doi.org/10.1093/cjres/rsx030.

[5] Cf. Thomas Schmitz (note 3), p. 168, $215 \mathrm{ff}$.

[6] Federal Constitutional Court [Bundesverfassungsgericht], Maastricht judgement of 1993, BVerfGE 89, 155 (decisions of the Bundesverfassungsgericht, vol. 89, p. 155 ff.); Lisbon judgement of 2009, BVerfGE 123, 267.

[7] See in particular Ingolf Pernice, Theorie und Praxis des Europäischen Verfassungsverbundes [Theory and Practice of the European Constitutional Compound], WHI Paper 8/2008, www.rewi.hu-berlin.de/de/lf/oe/whi/publikationen/ whi-papers/2008/whipaper0808.pdf.; Ingolf Pernice, The EU - a Citizens' Joint Venture. Multilevel Constitutionalism and Open Democracy in Europe, WHI Paper 09/2013, p. 3 f., www.rewi.huberlin.de/de/lf/oe/whi/ publikationen/whi-papers/2013/whi-paper-09-2013.pdf.

[8] See in particular Christian Calliess (editor.), Verfassungswandel im europäischen Staatenund Verfassungsverbund. Göttinger Gespräche zum deutschen und europäischen Verfassungsrecht [Constitutional Change in the European Compound of States and Constitutions. The Göttingen Talks on German and European Constitutional Law], 2007.

[9] Cf. Arnim von Bogdandy, Supranationale Union als neuer Herrschaftsträger: Entstaatlichung und Vergemeinschaftung in staatstheoretischer Perspektive [The Supranational Union as a New Ruler. Denationalisation and Communitarisation from the Perspective of General Theory of State], in: Integration 1993, p. 210 ff.; Thomas Schmitz (note 3), p. 74 with further references.

[10] See on this concept Thomas Schmitz, Integration through Law - the European Approach of Supranational Geo-regional Integration, in: ASEAN Studies Center, Faculty of Social \& Political Sciences, Universitas Gadjah Mada (editor): Conference Proceeding: International Conference on ASEAN Studies (ICONAS 2019): Rethinking Law, Institution and Politics in Advancing Partnership for Sustainable ASEAN Community, Yogyakarta, 13.-14.03.2019, 
2019, http://asc.fisipol.ugm.ac.id/wp-content/uploads/sites/741/2020/03/CONFERENCEPROCEEDINGS-ICONAS-2019.pdf, p. 1 ff.

[11] Https://curia.europa.eu. Note that this court must be distinguished from the European Court of Human Rights in Strasbourg (the treaty body under the European Convention of

Human Rights, www.echr.coe.int). The latter is not an institution of the European Union.

[12] ECJ, case 26/62, van Gend \& Loos, [1963] ECR 1, p. 23 ff. Strictly speaking, in the legal world order of sovereign states there can only be domestic and international law and European Union law is a part of international law. However, this part is so different from (other) public international law and so developed that most rules of international law do not apply and that it is generally recognised as a distinct and autonomous legal order.

[13] Cf. ECJ, case 11/70, Internationale Handelsgesellschaft, no. $3 \mathrm{f}$.

[14] ECJ, case 26/62, van Gend \& Loos, headnote 5.

[15] ECJ, case 6/64, Costa/ENEL.

[16] ECJ, case 79/83, Ratti, no. $19 \mathrm{ff}$.

[17] Cf. ECJ, case 11/70, Internationale Handelsgesellschaft, no. $3 \mathrm{f}$.

[18]This limit was first worked out by the Italian Constitutional Court [Corte costituzionale], judgement 183/73, Frontini Franco, www.giurcost.org/decisioni/1973/0183s-73.html, and the German Federal Constitutional Court, BVerfGE 37, 271 (see p. 277 ff.), "Solange I", English translation at https://law.utexas.edu/transnational/ foreign-law-translations/german/case.php?id=588, and BVerfGE 73, 339 (see p. 366 ff.), "Solange II", English translation at https://law.utexas.edu/transnational/foreign-law-translations/german/case.php?id=572. Nowadays there is common sense about it, see for example French Constitutional Council, decision of 27.07. 2006, 2006-540 DC, no. 19, www.conseil-constitutionnel.fr/decision/2006/2006540DC.htm.

[19] Note on terminology: When European integration started with three European Communities, the European law was called Community law. In 1993 the Communities became part of the European Union and Community law the most important part of Union law. The Treaty of Lisbon, which entered into force in 2009, abandoned the European Community as distinctive part within the Union, and, thus, the distinction between Community law and Union law.

[20] See on these principles Thomas Schmitz, The general principles of European Union law - a source of inspiration for the development of a modern administrative law in the Republic of Moldova, Administrarea Publică 2017, no. 1 (93), p. 26 ff., http://aap.gov.md/files/publicatii/revista/17/AP_1_17.pdf.

[21] See on the significance of the "effet utile" in European Union law Łukasz Stepkowski, The notion of effectiveness in the law of the European Union, Studia nad Autorytaryzmem i

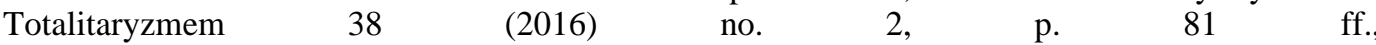
http://sfzh.wuwr.pl/download.php?id=479e62064724e01e54cc9db8f1d89788292eef8b; Alenka Berger Škrk, Effet utile and national practice: Is there a room for improvement?, InterEULawEast 1 (2014), no. 1, p. 113 ff., https://hrcak.srce.hr/123278; Sibylle Seyr, Der effet utile in der Rechtsprechung des Europäischen Gerichtshofs [The Effet Utile in the Jurisprudence of the European Court of Justice], 2008; Francis Snyder, The Effectiveness of European Community Law: Institutions, Processes, Tools and Techniques, The Modern Law Review 56 (1993), p. 19 ff., www.francis-snyder.com/tl_files/

contents/articles/\%20The_Effectiveness_of_European_Community_Law.pdf.

[22] See now for a recent analysis Attila Vincze, Europäisierung des nationalen Verwaltungsrechts - eine rechtsvergleichende Annäherung [Europeanisation of National administrative law - a Comparative Approach], in: Zeitschrift für ausländisches öffentliches Recht und Völkerrecht 77 (2017), p. 235 ff., www.zaoerv.de/77_2017/77_2017_1_a_235_268.pdf; J.H. Jans; S. Prechal; R.J.G.M. Widdershoven (editors), Europeanisation of Public Law, $2^{\text {nd }}$ edition 2015.

[23] ECJ, See on legal certainty as a general principle of Union law Juha Raitio, in: Ulf Bernitz; Joakim Nergelius; Cecilia Cardner; Xavier Groussot (editors), General Principles of EC Law in a Process of Development, 2008, p. $47 \mathrm{ff}$.; see for the limitation of retroactive effects ECJ, case C293/04, Beemsterboer, no. 24 f.

[24] ECJ, case 21/81, Bout, no. 13; case C-293/04, Beemsterboer, no. 24.

[25] Cf. ECJ, case C-496/08 P, Serrano, no. 84 with further references.

[26] ECJ, case 222/84, Johnston, no. 18 f.; case 222/86, Heylens, no. 14.

[27] This principle represents a core element of the rule of law and thus applies as a general principle of law in the whole legal order of the European Union, cf. Cordula Stumpf, in: Jürgen Schwarze (editor), EU-Kommentar [EU Commentary], 2 ${ }^{\text {nd }}$ edition 2009, art. 6 EUV [= EU Treaty], no. 11 with further references.

[28] See Thomas Schmitz (note 20), p. 26 (31 f.).

[29] Cf. ECJ, case C-255/90, Burban, no. 7, 12; joint cases 33 and 75/79, Kuhner, no.23 ff. 
[30] See in particular Friedrich Schoch, Die Europäisierung des Allgemeinen Verwaltungsrechts [The Europeanisation of General Administrative Law], in: Juristenzeitung 1995, p. 109 ff.; Friedrich Schoch, Die Europäisierung des verwaltungsgerichtlichen vorläufigen Rechtsschutzess [The Europeanisation of Interim Relief by the Administrative Courts], in: Deutsches Verwaltungsblatt 1997, p. 289 ff.; see also Rupert Scholz, Zum Verhältnis von europäischem Gemeinschaftsrecht und nationalem Verwaltungsverfahrensrecht [On the Relationship between European Community Law and National Administrative Procedural Law], Die Öffentliche Verwaltung 1998, p. 261 (265); further references to the discussion at Thomas Schmitz (note 3), p. 110.

[31] ECJ, case 26/62, van Gend \& Loos, [1963] ECR 1, 23 ff.

[32] ECJ, case 6/64, Costa/ENEL, [1964] ECR 585 ff.

[33] ECJ, case 11/70, Internationale Handelsgesellschaft, no. $3 \mathrm{f}$.

[34] See, with regard to directives, ECJ, case 79/83, Harz, summary 1.

[35] ECJ, joint cases 205-215/82, Deutscher Milchkontor, no. 17 ff.

[36] ECJ, joint cases 205-215/82, Deutscher Milchkontor, no. 33.

[37] ECJ, case C-217/88, vin de table (Commission v. Germany), no. 14 ff., 33.

[38] See on this topic now Attila Vincze, Die Europäisierung der verwaltungsgerichtlichen Klagebefugnis - eine rechtsvergleichende Analyse [The Europeanisation of the Right of Action - a Comparative Analysis], in: Faculty of Comparative Political and Legal Studies of the Andrássy University Budapest (editor), Jahrbuch für Vergleichende Staats- und Rechtswissenschaften 2014/2015, 2016, p. 55 ff. with further references.

[39] ECJ, case C-213/89, Factortame, no. $20 \mathrm{ff}$.

[40] ECJ, joint cases C-143/88 and others, Zuckerfabrik Süderdithmarschen, no. 16 ff., 22 ff.

[41] ECJ, case C-24/95, Alcan, no. 25, 34.

[42] Cf. ECJ, case 9/0, Leberpfennig (Franz Grad), no. 5 ff.

[43] ECJ, joint cases C-6/90 and C-9/90, Francovich, no. $31 \mathrm{ff}$. This jurisprudence has been further developed in ECJ, joint cases C-46/93 and C-48/93, Brasserie du Pêcheur/Factortame, no. 16 ff.

[44] Cf. ECJ, joint cases C-46/93 and C-48/93, Brasserie du Pêcheur/Factortame, no. 32; case C224/01, Köbler, no. 32 ff., 51 ff. ।

[45] Cf. ECJ, case C-361/88, TA-Luft (Commission v. Germany), no. 20 f., 24.

[46] ECJ, case C-129/96, Inter-Environnement Wallonie, no. $44 \mathrm{ff}$.

[47] Cf. ECJ, case 79/83, Harz, summary 1.

[48] Cf. ECJ, case 148/78, Ratti, no. 19 ff.

[49] Cf. ECJ, joint cases C-6/90 and C-9/90, Francovich, no. 31 ff.; case C-392/93, British Telecommunications, no. $40 \mathrm{ff}$.

[50] Federal Constitutional Court, Lisbon judgement, BVerfGE 123, 267 (347, 354).

[51] See in particular the new art. 23 of the Basic Law for the Federal Republic of Germany of 1949 and Title XI (art. 88-1 et seq.) of the Constitution of the French Republic of 1958.

[52] Cf. ECJ, case C-285/98, Tanja Kreil.

[53] See, for example, Federal Constitutional Court, fire service levy for men, BVerfGE 92, 91, de facto following European Court of Human Rights, judgement of 18.07.1994, Karlheinz Schmidt v. Germany, https://hudoc.echr.coe. int/eng\#\{"itemid":["001-57880"]\}.

[54] See already Franz-Joseph Peine; Anna Samsel, Die Europäisierung des Umweltrechts und seine deutsche Umsetzung [The Europeanisation of environmental law and its German implementation], in: Europäisches Wirtschafts- und Steuerrecht 2003, p. 297 ff.

[55]See Thomas Schmitz, The implementation of the rights of refugees and asylum seekers in Europe and Germany, lecture at the National Seminar "Refugees and Asylum Seekers in Indonesia: Upstream and Downstram of Issue Handling, the Protection of Human Rights and its Implications for the Security of the State Border" at Universitas Muhammadiyah Buton, 08.02.2020, www.thomas-schmitz-yogyakarta.id/Downloads/Schmitz_Asylum-Refugee-RightsEU-Germany.pdf, p. $1 \mathrm{f}$.

[56] See Hanane Ouirini, Essai sur l'européanisation du droit de la consommation [Essay on the Europeanisation of Consumer Law], doctoral thesis in law, University of Avignon, 2016.

[57] Regulation $2016 / 679$ on the protection of natural persons with regard to the processing of personal data and on the free movement of such data, and repealing Directive 95/46/EC (General Data Protection Regulation).

[58] See, for example, Hannes Rösler, Europeanisation of Private Law through Directives Determining Factors and Modalities of Implementation, European Journal of Law Reform 11 (2009), p. 305 ff.; Jan von Hein; Eva-Maria Kieninger; Giesela Rühl, How European is European Private International Law?, 2019. 
[59] Cf. Edita Gruodyte; Ingrida Kairiene, The Europeanisation of Criminal Law in the Member States, in: Administrativa un Kriminala Justicija 2009, Nr.2, p.32 ff.; Libor Klimek, The European Arrest Warrant, 2014.

\section{Table of Jurisprudence}

Note: All judgements of the European Court of Justice (= ECJ) are easily accessible in English at the Court's website (https://curia.europa.eu/jcms/jcms/j_6/en). Please just insert the case number into the search mask of the database!

ECJ, case 26/62, Van Gend \& Loos [1963] (Community law as an independent legal order; direct applicability of primary Community law)

ECJ, case 6/64, Costa/ENEL [1964] (primacy of Community law)

ECJ, case 11/70, Internationale Handelsgesellschaft [1970] (primacy of Community law over national constitutional law)

ECJ, case 148/78, Ratti [1979] (direct applicability of directives in favour of the citizen after expiration of the implementation period)

ECJ, joint cases 205-215/82, Deutscher Milchkontor [1983] (implementation of Community law by the member states; recovery of amounts unduly paid)

ECJ, case 79/83, Harz [1984] (interpretation of national law in the light of directives)

ECJ, case 222/84, Johnston [1986] (right to effective legal protection).

ECJ, case 222/86, Heylens [1987] (statement of reasons for administrative decisions).

ECJ, case C-217/88, vin de table [1990] (obligation to take coercive measures to enforce the law)

ECJ, case C-213/89, Factortame [1990] (interim relief to enforce Community law)

ECJ, joint cases C-143/88 and others, Zuckerfabrik Süderdithmarschen [1991] (interim relief against implementation of Community law)

ECJ, case C-361/88, TA-Luft [1991] (no implementation of directives through administrative practice or administrative provisions)

ECJ, joint cases C-6/90 and C-9/90, Francovich [1991] (state liability pursuant to Community law)

ECJ, joint cases C-46/93 and C-48/93, Brasserie du Pêcheur/Factortame [1996] (state liability pursuant to Community law for violation of directly applicable provisions)

ECJ, case C-24/95, Alcan [1997] (recovery of illegal state aids and protection of legitimate expectations)

ECJ, case C-129/96, Inter-Envirionnement Wallonie [1997] (precursory effect of directives during implementation period)

ECJ, case C-224/01, Köbler [2003] (state liability for violations of Community law by supreme court judgements)

ECJ, case C-293/04, Beemsterboer [2006] (protection of legitimate expectations) 